\title{
S TOUHOU ODKRÝVAT... PRVNÍCH DVACET LET EXISTENCE STÁTNÍHO ARCHEOLOGICKÉHO ÚSTAVU
}

\author{
MARCELA STARCOVÁ
}

\begin{abstract}
Abstrakt: V roce 1919 byl založen Státni archeologický ústav, jehož úkolem bylo kromě vědeckého výzkumu vybudovat oborovou infrastrukturu a pečovat o archeologické dědictví na územi ČSR. Archeologické výzkumy vedli státni konzervátoři, spolupracujici s regionálními pracovníky muzeí i amatérskými sběrateli. $Z$ důvodu nedostatku finančních prostředků prováděli zejména záchranné výzkumy. Systematické výzkumy byly spolufinancovány dalšimi institucemi, napřiklad Národním fondem Masarykovým. Statut Státního archeologického ústavu v roce 1934 deklaroval povinnost evidence všech prehistorických nálezů na území státu. Tuto povinnost převzal nově založený Archiv nálezových zpráv. Pozdějši ředitel ústavu Jaroslav Böhm vypracoval a prosadil moderni zásady vedeni terénnich výzkumů, stejně jako modernizaci terénní dokumentace. Novou koncepci směrováni však nestihl prosadit z di̊vodu vyhlášeni protektorátu Čechy a Morava.
\end{abstract}

Klíčová slova: Státní archeologický ústav - státní konzervátoři - Národní fond Masarykův - Jaroslav Böhm-Archiv nálezových zpráv.

\section{With a desire to unearth... The first twenty years of the State Institute of Archaeology}

Abstract: The State Institute of Archaeology was established in 1919. Its objectives were, apart from scientific research, the creation of the infrastructure for the branch and care for the archaeological heritage in the territory of the Czechoslovak Republic. Archaeological research was led by state conservators collaborating with regional museum workers, as well as with amateur collectors. Owing to a lack of finance, archaeologists predominantly conducted rescue research. Systematic research was co-financed by other institutions, for example, by the Masaryk National Foundation. In 1934 the statutes of the State Institute of Archaeology declared obligatory cataloguing of all prehistoric finds in Czech territory This task was performed by the newly established Archive of Find Reports. Jaroslav Böhm, later the institute director, formulated and pushed through modern principles of conducting field survey, along with the modernization of field documentation. Regrettably, he did not manage to put this new direction concept into practice due to the establishment of the Protectorate of Bohemia and Moravia.

Key words: State Institute of Archaeology - state conservators - Masaryk National Foundation - Jaroslav Böhm-Archive of Find Reports.

\section{Úvod}

Státní archeologický ústav (dále StAÚ) byl založen výnosem Ministerstva školství a národní osvěty ze dne 12. listopadu 1919. Duchovním otcem StAÚ a zároveň prvním ředitelem se stal antropolog, archeolog a slavista Lubor Niederle. Podle Niederlova propracovaného konceptu vědecké práce se měl ústav věnovat základním systematickým výzkumům, ochraně pravěkých památek, zapojit se do mezinárodní spolupráce v klasické i orientální archeologii. Do detailu promyšlený velkorysý plán však předběhl svou dobu o celá desetiletí (Niederle 1919, 1-2).

V prvním desetiletí své existence se Státní archeologický ústav potýkal s řadou praktických problémů: kromě stálého akutního nedostatku financí šlo i o omezené prostory pro práci a nedostatek odborných pracovníků. V prvních letech pracovalo v ústavu pouze šest zaměstnanců, kteří brzy přestali zvládat nápor administrativních úkolů i množství práce v terénu. Činnost ústavu se proto zpočátku omezovala na záchranné výzkumy, s několika výjimkami, jako byl například výzkum Pražského hradu a Vyšehradu. K větším badatelským odkryvům došlo až na přelomu 20. a 30. let s finanční podporou Národního fondu Masarykova. 


\section{Personální situace}

Prvních deset let strávili pracovníci StAÚ v omezených (v podstatě provizorních) prostorách Strahovského kláštera, kde měli k dispozici bývalý zimní refektář a dvě další místnosti. Zde se soustředila veškerá administrativa instituce, zpracování hlášení a nálezových zpráv, stejně jako konzervace a fotografování nalezených předmětů. Se zvýšeným počtem zaměstnanců v průběhu 20. let a nutností zpracovávat rostoucí množství nálezů tyto prostory záhy přestaly vyhovovat. V roce 1930 se StAÚ přestěhoval do Lobkovického paláce na Malé Straně, kde mu bylo přiděleno dvanáct místností. Postupně byly vybudovány keramická laboratoř, fotografický ateliér, knihovna s př́ručkou a studovnou a depozitář v bývalé konírně (Kuna-Starcová-Maříková-Kubková 2019, 28-29). Na této adrese instituce s malými přestávkami zůstala až do roku 1951.

Archeologické výzkumy a jejich evidenci měli na starosti tzv. státni konzervátoři. Státním konzervátorem pro Čechy - a zároveň tzv. „prvním konzervátorem“ - byl jmenován Josef Antonín Jíra. Sídlil v Praze a staral se o agendu a provádění terénních výzkumů v Čechách, jakož i o publikování jejich výsledků. Rozděloval také konzervovaný a publikovaný materiál z výzkumů jednotlivým muzeím. Vedl registry všech nálezů na území republiky a evidenci všech nalezišt' dosud neprozkoumaných. Oceňoval sbírky a navrhoval nákupy veřejného majetku. Byl povinen vést laboratoř a pražskou kancelář, podílel se spolu s ředitelem na korespondenci a kontrole účetnictví ústavu, zastupoval ředitele v jeho nepř́ítomnosti. Moravu a Slezsko měl na starosti Innocenc Ladislav Červinka, Slovensko Jan Eisner. Záhy po založení StAÚ bylo nutné přijmout další pracovníky. V roce 1922 nastoupil Antonín Salač, specialista na antickou archeologii, o rok později pak Ivan Borkovský jako pomocná vědecká síla a Jaroslav Böhm jako placený volontér. ${ }^{1}$ V polovině 20. let posílili personální obsazení ústavu Emanuel Šimek, který měl na starosti památkovou agendu, konzervátorem pro antické památky byl jmenován Anton Gnirs. V roce 1926 už pracovalo v ústavu celkem čtrnáct lidí. V závěru 20. let zaměstnal StAÚ první profesionální archeoložku - Libuši Jansovou (MÚA, StAÚ, č. kart. 2).

Vzhledem k počtu hlášených nálezů a záchranných výzkumů byli ovšem státní konzervátoři nuceni opírat se o spolupracovníky nejen z regionálních muzeí, ale také z řad amatérských sběratelů či podporovatelů archeologie. $S$ ústavem spolupracovali například učitelé, úředníci, často také zemědělci a četníci. Na základě Statutu Státního archeologického ústavu, vydaného v roce 1934, byla postupně budována rozsáhlá sít' externích spolupracovníků - jednatelů, dopisovatelů a okresních konzervátorů. Tyto spolupracovníky vybírali a navrhovali ke schválení státní konzervátoři pro jednotlivé země, poté byli jmenováni ministrem školství na dobu určitou. ${ }^{2}$ Všechny tři funkce byly čestné, bez nároku na odměnu (MÚA, StAÚ, inv. č. 30-33). Podle dochovaných archivních pramenů došlo ke jmenování jednatelů pouze ve dvou funkčních obdobích, v letech 1935 a 1940. Po válce už znovu jmenováni nebyli, i když řada z nich spolupráci s ústavem nepřerušila (Charvátová-Spurný-Venclová 1992, 6). Sít konzervátorů vytvořil Státní památkový úřad již ve 20. letech, ti se však věnovali zejména ochraně hmotných a přírodních památek. Státní archeologický ústav navrhoval rozš́iřit tuto sít' také o konzervátory pro ochranu památek archeologických (Charvátová-Spurný-Venclová 1992, 5-6). Většina konzervátorů Státního památkového úřadu spolupracovala i se StAÚ a hlásila nálezy, př́ípadně výkopy. Oficiálně byla tato spolupráce deklarována až ve výnosu Ministerstva školství a národní osvěty z 3. prosince 1935 (MÚA, StAÚ, inv. č. 33).

Ani ve 30. letech nebylo personální obsazení ústavu zdaleka ideální. Nastoupili sice další odborníci (Antonín Knor, Vojtech Budaváry/Budinský-Krička, Jan Rataj), přesto disponoval ústav k 1. lednu 1939 pouze devíti pracovními silami (bez ředitele), z toho pěti odborníky. Akce k nápravě katastrofálního personálního stavu skončila k 1. dubnu 1940, kdy měl ústav k dispozici

\footnotetext{
1 Volontér - pracovní pozice pomocné síly s fixním platem 500 Kčs měsíčně. Nejednalo se o stálé pracovní místo, započítávalo se však do penzijního pojištění. Ve 20 . letech sloužila tato pozice jako přechodné zaměstnání pro studenty, ve 30 . letech představovala především formu nouzového řešení nezaměstnanosti v rámci akce na podporu nezaměstnané inteligence (Rataj-Šolle-Vencl 2003, 142).

2 Jednatelé byli jmenováni na dobu 5 let, konzervátoři na dobu 3 let (pozn. aut.).
} 
28 zaměstnanců - ovšem zčásti jen na papíře: více než třetina $\mathrm{z}$ nich pracovala i pro jiné instituce (např́iklad fotograf vypomáhal i v Památkovém úřadu či v Orientálním ústavu) a část personálu byla přijata $\mathrm{v}$ rámci akce na podporu nezaměstnané inteligence, $\mathrm{tj}$. pouze krátkodobě a bez odpovídajícího vzdělání (MÚA, StAÚ, inv. č. 39, 40). ${ }^{3}$

\section{Záchranné a systematické výzkumy}

Záchranné archeologické výzkumy byly prováděny na základě písemného nebo telefonického hlášení, často však také v reakci na články v denním tisku. Zprávy tisku ovšem byly často nepřesné, takže pracovníci ústavu měli plné ruce práce s vyvracením omylů (obr. 1). Postup řešení

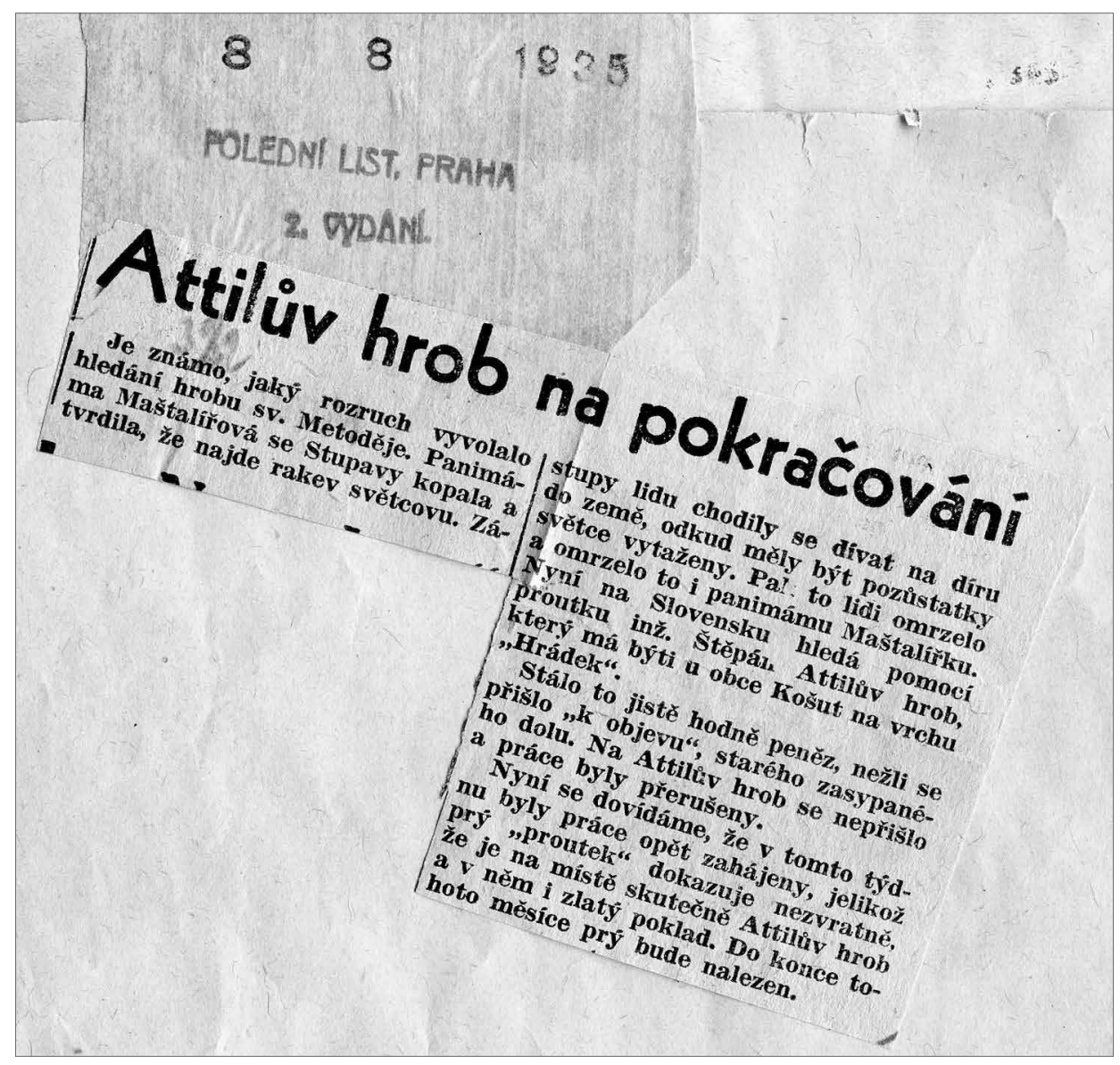

Obr. 1. Attilův hrob na pokračování. Denní tisk v roce 1935 sledoval neúspěšné hledání Attilova hrobu, které prováděl amatérský nadšenec Ing. František Štěpán na kopci Hrádok u obce Priekopy, severně od Martina. Polední list z 8. srpna 1935. Zdroj Archiv ARÚP, C-TX-193501901.

Abb. 1. Attilas Grab - Fortsetzung folgt. Die Tagespresse verfolgte im Jahr 1935 die erfolglose Suche nach Attilas Grab, die nördlich von Martin bei der Gemeinde Priekopa von dem Amateurenthusiasten Ing. František Štěpán auf dem Hügel Hrádok durchgeführt wurde. Mittagsblatt vom 8. 8. 1935. Quelle Archiv des Archäologischen Instituts Prag, C-TX-193501901.

$3 \mathrm{~V}$ rámci akce na podporu nezaměstnané inteligence byli penzionováni starší zaměstnanci a provdané ženy, jejichž manželé pracovali rovněž ve státní službě, byly jako ekonomicky zaopatřené propuštěny. $Z$ toho důvodu odešla v roce $1934 \mathrm{z}$ ústavu L. Jansová. 
prŕpadů, kdy informace o nálezu přinesly noviny, najdeme např́klad ve vzpomínkách dlouholetého pracovníka ústavu, tehdejšího volontéra, Jana Rataje. „Jednoho dne v srpnu 1937 vešel do naši pracovny ředitel Buchtela v doprovodu sekretářky sl. Bařtipánové: ,Pane volontére, $v$ dnešním tisku je zpráva o nálezu kostry v ulici Ve svahu na Vyšehradě. Policie bude žádat urychlené vyšetřeni př́padu, nejde-li o zločin. Pan komisař [správní osvětové služby - pozn. aut.] byl již několikrát v podobné situaci a pouči vás. Prosím vás, pane volontére, ujměte se ihned připadu!' Dr. Budaváry ... mne instruoval: ,Pane kolego, vezměte si ihned tašku s nástroji a odjed'te na misto nálezu, tam kostru vyfotografujte a hledejte součásti vojenské výstroje a knofliky. Tamni policista od Vás přijme písemné vyjádřeni o stář́ hrobu (přes 90 let) nebo použijte pro tisk termín hrob z tereziánské doby a policie přestane o hrob jevit zájem. Dopis vám již sl. sekretářka přichystala. “ " (Rataj-Šolle-Vencl 2003, 145)

Někteří dlouholetí regionální spolupracovníci, zejména z okolí Prahy, navštěvovali ústav i osobně, aby nahlásili nálezy ohrožené - nejčastěji stavební činností. Výjimečně se objevovala i anonymní udání, která musela být rovněž prošetřena. Některá hlášení obsahovala i varování před amatérskými kopáči pokladů, např́ílad 2. září 1920 byla Státním památkovým úřadem postoupena ústavu informace o amatérském kopání na Libušíně. „Na hradišti Libušině u Kladna kopou bez dozoru nějaci dělníci. Nalézaji prý tam zlato, stř́bro a drahé kamení; jsou z toho celí rozrušení a podráždění. Tomu, kdo tam pojede, doporučuje se opatrné jednání s dělníky a žádá se, aby nebylo jim hlášeno, jak tato zpráva o jejich kopání došla do Prahy." Informaci prý telefonicky podal Státnímu památkovému úřadu patronátní úřad ve Smečně, písařka pak zprávu postoupila do StAÚ ve 12 hodin. A státní konzervátor J. A. Jíra reagoval bleskově. „V $1 h$ [odinu] $4 m$ [inuty] vypravil jsem se vlakem z nádraži v Brusce do Kladna a odtud přes lesy (sedmkrát zmoknul) na hradiště v Libuš[íně]. Tam sešel jsem se náhodou s p. Zdeňkem Holfeldem, účetním patronátního úr̆adu ve Smečně, se kterým společně ohledali jsme zmíněné misto a shledali následujici situaci [...]“" (Archiv ARÚP, C-TX-192000120). Rychlost zásahu odborných pracovníků byla často klíčová, $\mathrm{v}$ řadě př́padů se archeologové dostali na místo nálezu až poté, co dělníci nalezené předměty vyzvedli a rozdělili si je, př́ípadně je vyhodili.

Jak vyplývá z výše uvedených citací, na výzkum či místo nálezu se státní konzervátoři i další pracovníci ústavu museli dopravit vlastními silami. Ústav měl sice vlastní kočár, ten však byl k dispozici především řediteli. Výjimečně mohli kočár využívat i odborní pracovníci ústavu, tzv. „kočárné“ bylo součástí cestovních výloh archeologů až do konce druhé světové války (Rataj-Šolle-Vencl 2003, 145). Ve většině případů museli pánové vzít zavděk veřejnou dopravou nebo absolvovat cestu pěšky (obr. 2). Nálezy pak přinášeli v aktovkách, podle pamětníků se také stávalo, že z výzkumů probíhajících v Praze, například v Bubenči nebo Dejvicích, vozili pracovníci nálezy do ústavu na zadní plošině tramvaje (Rataj-Šolle-Vencl 2003, 142).

Rozsáhlé systematické výzkumy byly finančně velmi nákladné a z rozpočtu StAÚ se nedařilo je pokrýt. Archeologické výzkumy řady významných lokalit mohly být v meziválečném období realizovány jen díky mimorozpočtovým příjmům - např́íklad prostřednictvím subvencí ministerstev, vlády, některých bank a pojišt'oven, ale zejména přispěním Národního fondu Masarykova (Elznicová Mikesková 2009). ${ }^{4}$ Z prostředků Národního fondu Masarykova (dále NFM) byly $\mathrm{v}$ Čechách podpořeny např́iklad systematické výzkumy na Pražském hradě, Vyšehradě nebo Libušíně, na Moravě v Dolních Věstonicích či v Mušově. Na Slovensku byly díky NFM prozkoumány římská stanice ve Stupavě a pohřebiště v Devínské Nové Vsi (Anonym 1931, 97-99; 1931a, 101).

4 Národní fond Masarykův byl založen v roce 1920 u prŕiležitosti prezidentových 70 . narozenin. Zákonem č. 318/1920 Sb. bylo jako čestný dar prezidentovi uvolněno ze státního rozpočtu 20 miliónů korun. Dalši prostředky fond získával z darů občanů, spolků, bank, velkých firem a korporací. O použití prostředků rozhodoval prezident osobně, podmínkou bylo využití financí na vzdělávací a humanitní účely. 


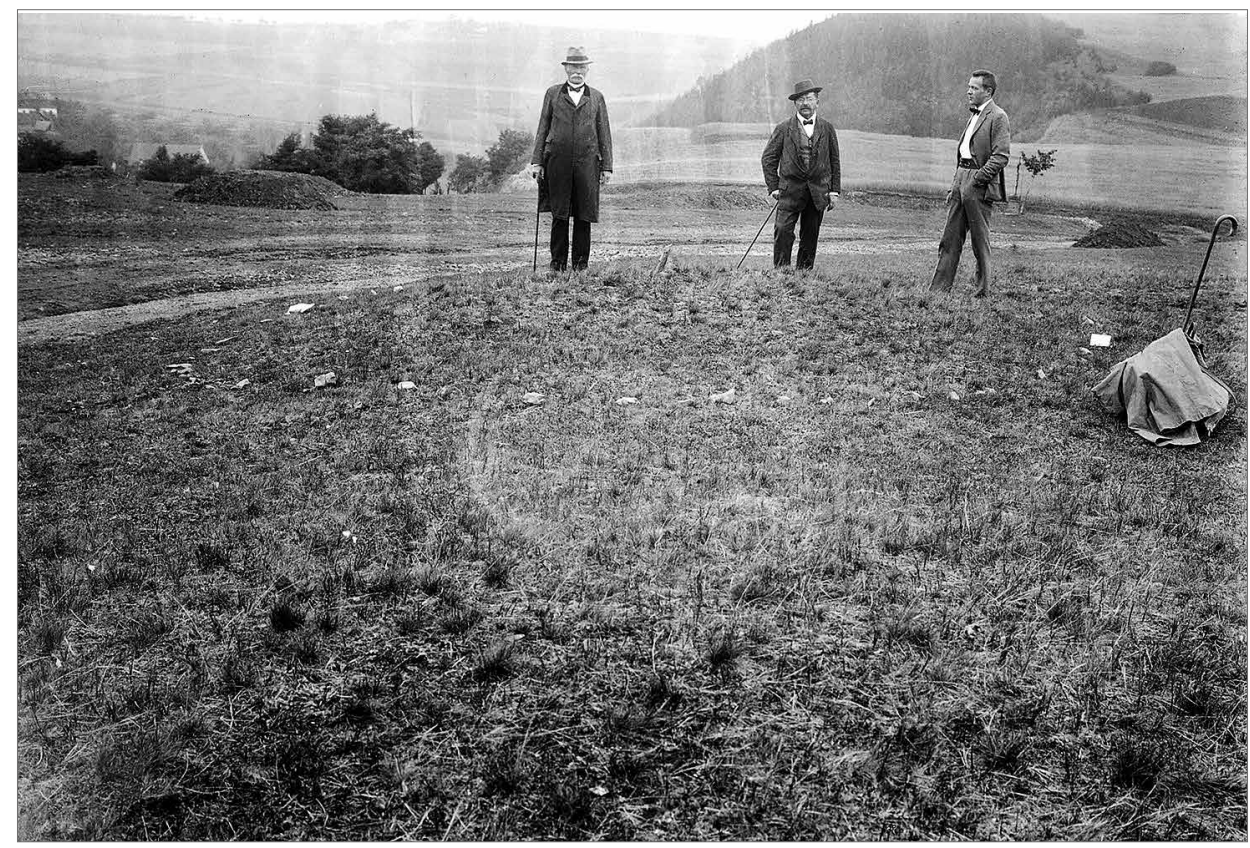

Obr. 2. Pohled na mohylu č. 1, 1922. Predikce archeologických památek v terénu. Výzkum raně stř̌edověkých mohyl v Hlohovičkách vedl J. A. Jíra. Foto A. Ševčík. Zdroj Archiv ARÚP, C-FT-000000265.

Abb. 2. Blick auf Grabhügel Nr. 1, 1922. Prädiktion archäologischer Denkmäler im Gelände. Die Grabung an den mittelalterlichen Grabhügeln in Hlohovičky wurden von J. A. Jíra geleitet. Foto A. Ševčík. Quelle Archiv des Archäologischen Instituts Prag, C-FT-000000265.

\section{Centrální evidence prehistorických nálezů a vznik Archivu nálezových zpráv}

Úkol centrálně shromažd’ovat a spravovat terénní dokumentaci archeologických výzkumů, stejně jako informace o archeologickém dědictví státu připadl StAÚ od počátku jeho existence. Explicitně byl tento úkol ústavu zadán Statutem Státního archeologického ústavu, který vydalo Ministerstvo školství a národní osvěty (dále MŠANO) v roce 1934 (MÚA, StAÚ, inv. č. 7). MŠANO tímto dokumentem formálně stanovilo hlavní povinnosti a úkoly StAÚ, a to jak na poli teoretického výzkumu, tak archeologické památkové péče. Náplní činnosti ústavu se měly stát široce založený vědecký výzkum naší minulosti, opřený a rozsáhlé badatelské výzkumy, a systematické shromažd’ování poznatků o archeologickém dědictví na území celého státu. Jak bylo výše uvedeno, na základě Statutu byla postupně budována sít' jednatelů, dopisovatelů a konzervátorů $\mathrm{z}$ řad odborné i laické veřejnosti, která významně přispěla $\mathrm{k}$ získávání komplexních informací o archeologických památkách na území ČSR.

První nálezové zprávy a hlášení o lokalitách s archeologickými nálezy byly zařazovány do spisové registratury StAÚ již od počátku 20. let, což bylo řešení přiměřené nízkému počtu terénních aktivit v prvním desetiletí existence ústavu. Situace se změnila v roce 1930, kdy se ústav přestěhoval do nového sídla v Lobkovickém paláci na Malé Straně a počet jeho zaměstnanců se zdvojnásobil. Spisová agenda registratury vzrostla natolik, že ředitel ústavu rozhodl o vyčlenění dokumentace terénních výzkumů do samostatného Archivu nálezových zpráv. Převodem nálezových zpráv ze spisové registratury do samostatného archivu byla pověřena Libuše Jansová (Spurný 1975, 150-151).

Archiv shromažd’oval dokumentaci z terénních výzkumů interních pracovníků i státních konzervátorů s mimopražským působištěm, dále pak informace od regionálních spolupracovníků, 
jednatelů a dopisovatelů StAÚ. K tomu přistupovaly zprávy a hlášení různých veřejných institucí, Státního památkového úřadu a jeho spolupracovníků, dále škol a četnických stanic i zprávy a sdělení jednotlivých občanů. Mnoho nálezů bylo podchyceno sledováním zpráv v denním tisku prostřednictvím výstřižkové služby. Údaje o nálezech z literatury rozepisovaly úřednice ústavu (Marie Bařtipánová a Věra Paulová), pracovníci archivu zpracovávali excerpta a údaje z publikací s odbornou tematikou (Spurný 1975, 151).

Zároveň archiv už ve 30. letech zahájil rozsáhlou akci soupisů sbírek regionálních muzeí, která pokračovala až do 50. let. Podíleli se na ní zaměstnanci ústavu i regionální spolupracovníci a výsledkem byly ucelené soupisy významných, často dosud nepodchycených archeologických pramenů (Kuna-Starcová-Maříková-Kubková 2019, 46-47).

Veškeré takto získané informace se $\mathrm{v}$ archivu soustřed’ovaly do tzv. generálního katastru prehistorických nálezů, tvořeného archivem nálezových zpráv, lístkovým katalogem nalezišt' ve dvou řadách a lístkovým katalogem negativů ve dvou řadách (podle lokalit a kultur).

\section{Modernizace terénního výzkumu}

Rozvoj metod terénní archeologické práce patřil k zásluhám Jaroslava Böhma, pozdějšího ředitele StAÚ. Stál $\mathrm{v}$ čele profesionalizace oboru, patřil $\mathrm{k}$ zakladatelům a organizátorům moderního sídlištního archeologického výzkumu. Böhm u nás založil, vlastní praxí ověřil, kodifikoval a prosadil metodiku moderního výzkumu až do fáze publikace. Naleziště začala být zkoumána systematicky, terénní situace byly přesně zaměřovány a zakreslovány (začal se používat milimetrový papír), nálezy se evidovaly v inventárních knihách. Antropologický a osteologický materiál byl předáván ke zpracování specialistům, keramická a fotografická laboratoř fungovaly přímo v ústavu (Rataj-Šolle-Vencl 2003, 142).

V oblasti terénní dokumentace byl velký posun patrný např́iklad ze srovnání prvních terénních odkryvů s výzkumy z poloviny 30 . let (srov. obr. 3 a obr. 6). Hlášení a nálezové zprávy z prvních let existence ústavu jsou poznamenány nedostatkem odborného personálu. Archeologové si v terénu museli sami místo nálezu zaměřit a zakreslit. Často si svépomocí kopírovali katastrální mapy, kam zanášeli místa nálezů či výzkumů. Skicovali si polohu lokalit v terénu, polohu nálezů i objektů, zhotovovali plány (obr. 4). Sami si museli výzkum či nálezy vyfotografovat a kvalita snímků byla mnohdy velmi rozdílná (obr. 5). Situace se měnila jen pozvolna, s nástupem odborných pracovníků. V průběhu 30. let nastoupili do StAÚ techničtí pracovníci podílející se na zaměřování a zakreslování výzkumů či na fotografických pracích (Antonín Miller, Antonín Knor, Miroslav Netáhlík). Profesionální fotografy získal ústav až v roce 1939 - Rudolfa Podzemného a Josefa Škodu (MÚA, StAÚ, inv. č. 35).

Současně se Jaroslav Böhm snažil o modernizaci terénní dokumentace. Během 20. let si osvojil z literatury, návštěv kongresů i osobních kontaktů se zahraničními kolegy, včetně tzv. americké expedice, která do republiky přijížděla v letech 1928-1934 (Anonym 1931, 97-100; 1931a, 102; Böhm 1937, 14), ${ }^{55}$ znalosti aktuálních evropských dokumentačních standardů (obr. 6). Ty zahrnovaly vedle popisů nálezových okolností i jejich fotografování, stejně jako fotografování profilů, preparaci povrchů a podrobné plány nálezů vynášené na milimetrový papír (Kuna-Starcová-Maříková-Kubková 2019, 56-57). Dnes se snaha používat milimetrový papír k dokumentaci terénní situace jeví jako úsměvná, v meziválečném období se však prosazovala jen pomalu. Některé významné osobnosti oboru archeologie kresebnou dokumentaci výzkumu odmítaly, např́iklad Josef Schránil soudil, že „dobrý archeolog si všechno pamatuje, takže terénní nálezové situace zásadně nekresli“" (Rataj-Šolle-Vencl 2003, 157).

\footnotetext{
5 American School of Prehistoric Research (ASPR) organizovala pro studenty amerických univerzit každoroční letní cvičné výzkumy v Čechách, ale také v Podunaji. Účastníci pracovali na terénních výzkumech, aby se seznámili s materiálem a výzkumnými metodami. V ASPR organizoval tyto pobyty Vladimír Jaroslav Fewkes (Fuks). Nejvýznamnější společný česko-americký výzkum se uskutečnil na eneolitickém výšinném sídlišti Homolka u Stehelčevsi v letech 1929-1931 (Archiv ARÚP, NZ C-TX-192901306, C-TX-193100261, C-TX-193101748; KunaStarcová-Maříková-Kubková 2019, 54-55).
} 


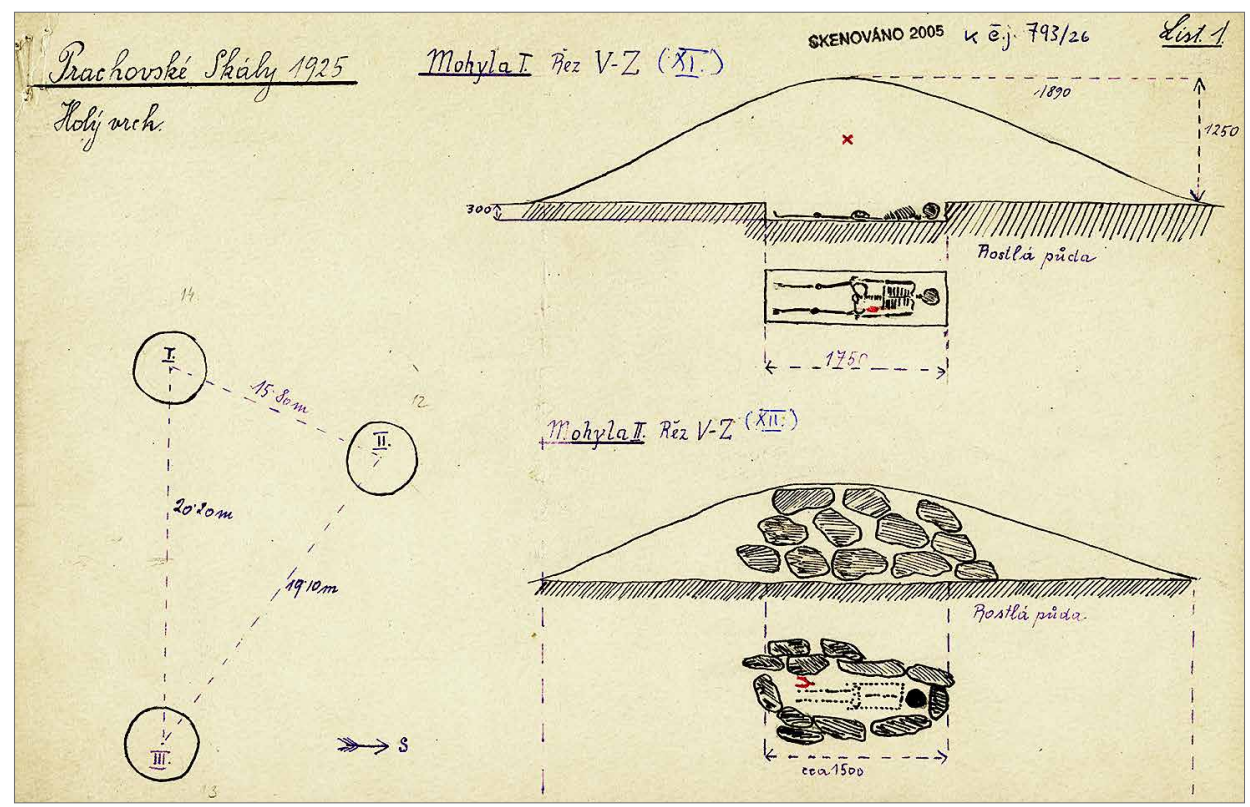

Obr. 3. Řez hradištními mohylami. Prachovské skály, poloha Holý vrch, 1925. Výzkum mohylového pohřebiště vedl J. Böhm. Autor plánku J. Böhm. Zdroj Archiv ARÚP, C-TX-192600793.

Abb. 3. Schnitt durch Burgwallgrabhügel. Prachauer Felsen, Lage Holý vrch, 1925. Die Grabung am Grabhügel wurde von J. Böhm geleitet. Planskizze J. Böhm. Quelle Archiv des Archäologischen Instituts Prag, C-TX-192600793.

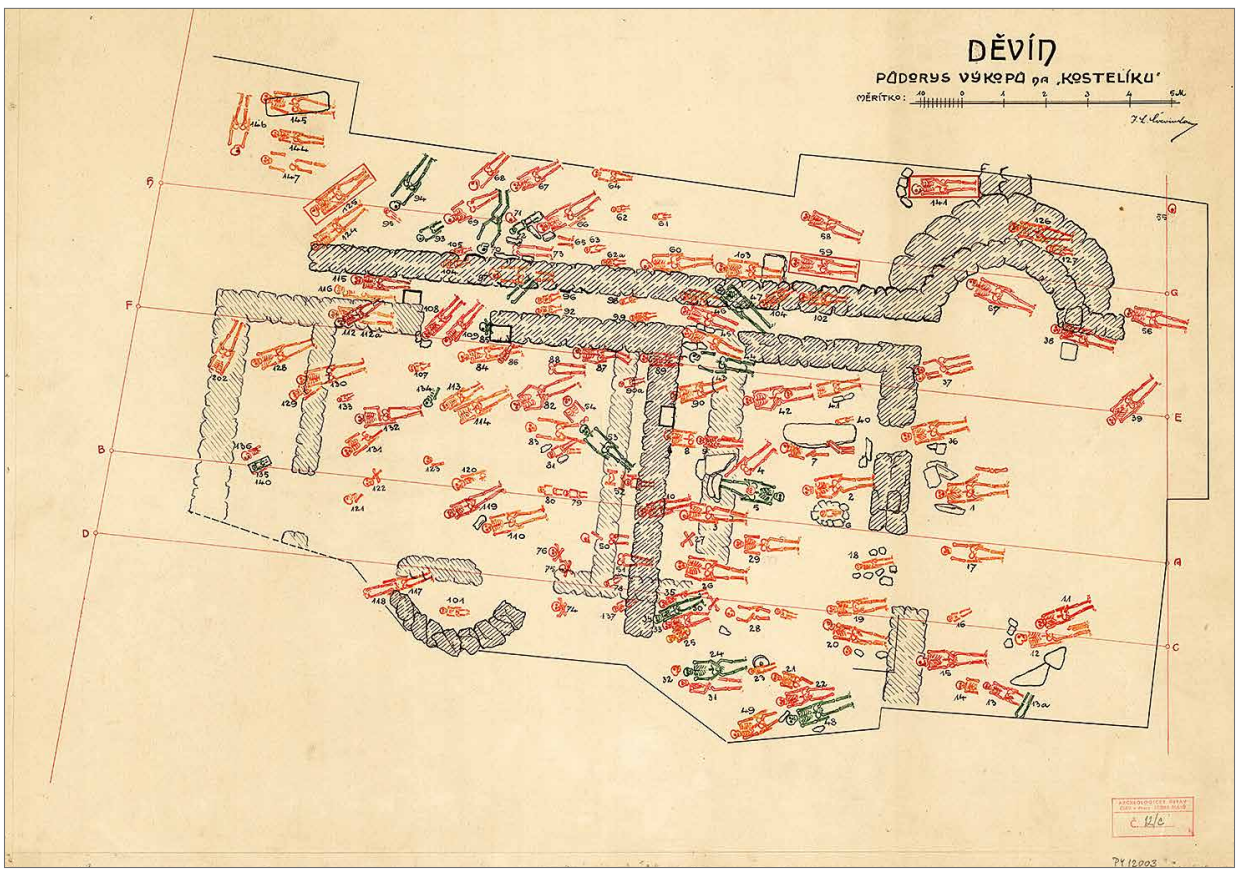

Obr. 4. Plán výzkumu na Děvínském hradě, v poloze Na kostelíku, 1921. Autor I. L. Červinka. Zdroj Archiv ARÚP, C-PY-000012003.

Abb. 4. Grabungsplan auf der Thebener Burg, Lage Na kostelíku, 1921. Planskizze I. L. Červinka. Quelle Archiv des Archäologischen Instituts Prag, C-PY-000012003. 


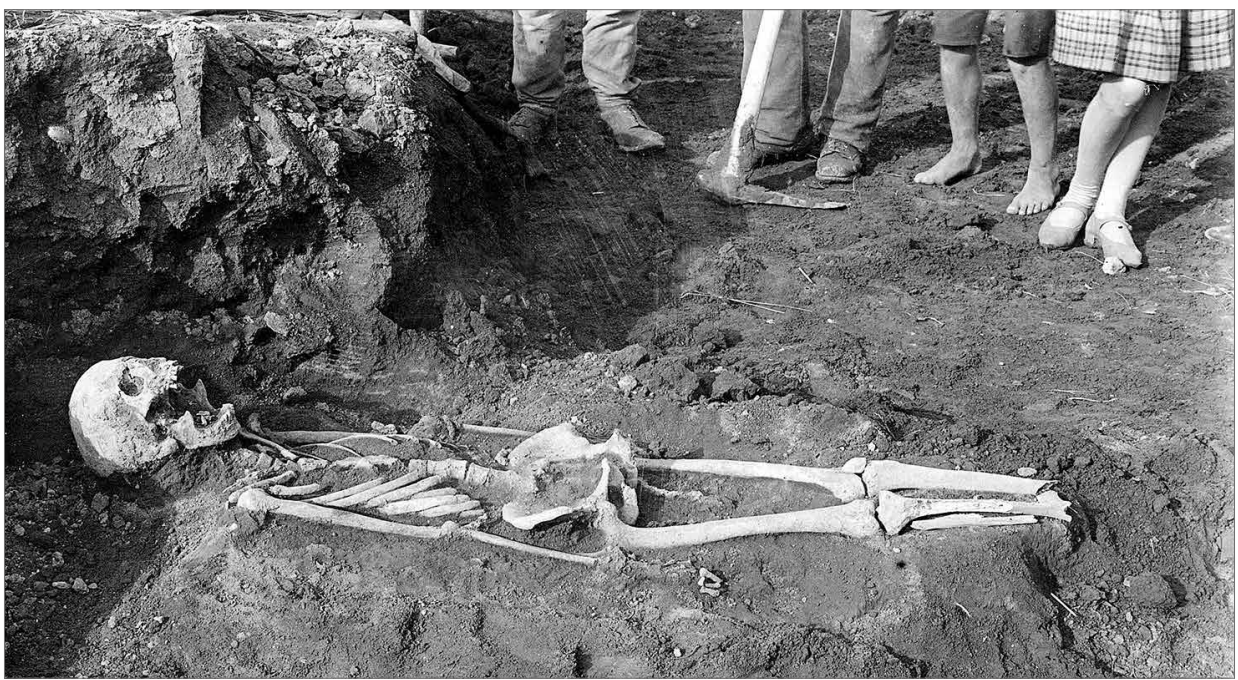

Obr. 5. Kouzlo nechtěného. Snímek kostrového hrobu i s nohama přihlížejících. Výzkum v Hoyermannově cihelně v Praze-Bubenči, rok neuveden. Zdroj Archiv ARÚP, C-FT-000000546.

Abb. 5. Der Zauber des Ungewollten. Aufnahme eines Skelettgrabs mit den Beinen der Zuschauer. Grabung in der Ziegelei Hoyermann in Prag -Bubenec, ohne Jahresangabe. Quelle Archiv des Archäologischen Instituts Prag, C-FT-000000546.

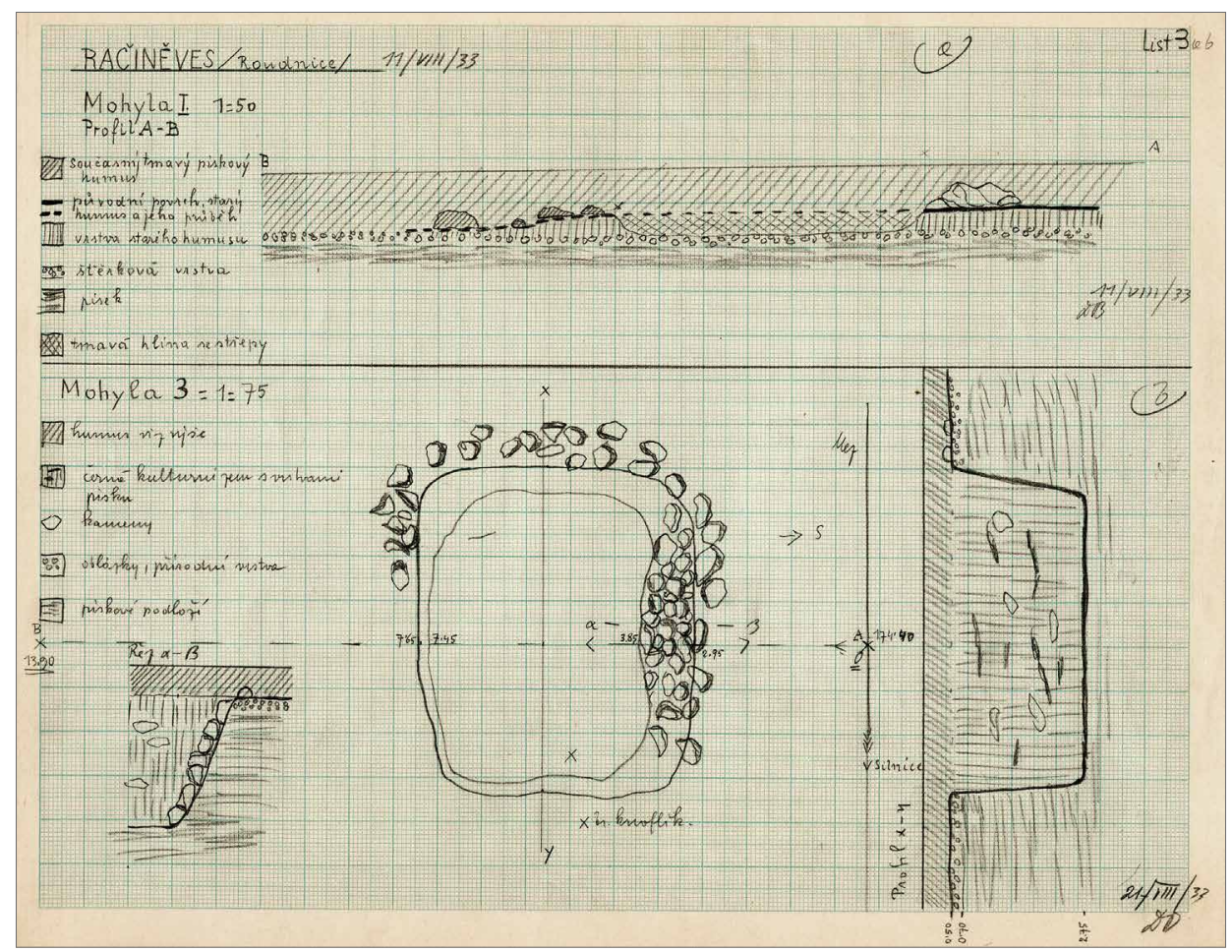

Obr. 6. Terénní dokumentace bylanských mohyl na milimetrovém papíře. Výzkum J. Böhma v Račiněvsi, 1933. Autor plánku J. Böhm. Zdroj Archiv ARÚP, C-TX-193301834.

Abb. 6. Geländedokumentation der Bylaner Grabhügel auf Millimeterpapier. Grabung von J. Böhm in Račiněves, 1933. Planskizze J. Böhm. Quelle Archiv des Archäologischen Instituts Prag, C-TX-193301834. 


\section{Závěr}

Po vyhlášení protektorátu byl StAƯ podřízen německé germanizační koncepci, těžiště práce se přesunulo do oblasti záchranných výzkumů. Původní struktura ústavu byla narušena: oblast Sudet byla podřízena samostatnému Úřadu pro pravěk (Amt für Vorgeschichte) se sídlem v Teplicích. Pro Archiv nálezových zpráv znamenala okupace vyčlenění oblasti Sudet těžkou ránu. Bylo nařízeno vybudovat samostatný německý archiv, což znamenalo přeložit české texty nálezových zpráv do němčiny a $\mathrm{k}$ překladům připojit originály kreseb, plánků a fotografíi z původní zprávy. V archivu StAÚ zbyla jen textová část bez dokumentace. Celá akce sice zůstala nedokončená, přesto však archiv utrpěl značné ztráty. Překlady českých textů byly zadávány mimo ústav a po válce se mnohé z dokumentů do archivu nevrátily (Spurný 1975, 152). Zároveň byla předána část terénní dokumentace Archivu nálezových zpráv spolu s nálezy na Slovensko. Po vyhlášení Slovenského štátu byl založen samostatný Slovenský archeologický ústav v Turčianském Sv. Martině (1939), v jeho čele stál až do roku 1951 Vojtech Budaváry (Budinský-Krička). Většina dokumentace a nálezů ze slovenských výzkumů, uložených ve StAÚ, byla do Slovenského archeologického ústavu převezena v letech 1938-1950 (MÚA, StAÚ, inv. č. 80, 81; Starcová v tisku).

V březnu 1939 byl jmenován do funkce ředitele StAÚ Jaroslav Böhm. Vypracovanou novou koncepci dalšího směřování ústavu se mu však už nepodařilo prosadit. Slibný vývoj instituce i její archeologické činnosti byl přerušen...

\section{Prameny a literatura}

ANONYM, 1931: Přehled o činnosti československého Státního archeologického ústavu v r. 1929. Zprávy Čsl. Státního archeologického ústavu, roč. II. a III. (za r. 1929 a 1930) Praha, 97-100.

- 1931a: Přehled o činnosti Čsl. Státního archeologického ústavu za r. 1930, Zprávy Československého Státního archeologického ústavu, roč. II. a III. (za r. 1929 a 1930). Praha, 101-105.

Archiv ARÚP: Archiv, Archeologický ústav AV ČR, Praha, v. v. i.

BÖHM, J., 1937: Československé nálezy v amerických publikacích, ZPP, sešit 5, 14.

ELZNICOVÁ MIKESKOVÁ, M., 2009: T. G. Masaryk - mecenáš československé archeologie. Výstava. Hornické muzeum Př́bram (8. 9. - 30. 10. 2009).

CHARVÁTOVÁ, K.-SPURNÝ, V.-VENCLOVÁ, N., 1992: Nálezové zprávy StAÚ 1919-1952. Praha.

KUNA, M.-STARCOVÁ, M.-MAŘÍKOVÁ-KUBKOVÁ, J. a kol., 2019: 100 let v archeologii. Objevy, nálezy a expedice Archeologického ústavu v Praze 1919-2019. Praha.

MÚA, StAÚ: Masarykův ústav a Archiv AV ČR, fond Státní archeologický ústav 1919-1952.

NIEDERLE, L., 1919: Před novými úkoly, PA XXXI, 1-2.

RATAJ, J.-ŠOLLE, M.-VENCL, S., 2003: Vzpomínky pracovníků Státního archeologického ústavu v Praze, AR LV, 139-165.

SPURNÝ, V., 1975: Nálezový archiv Archeologického ústavu ČSAV v Praze, ASM 10, č. 2, 150-158.

STARCOVÁ, M., v tisku: Jan Eisner a jeho působení na Slovensku v letech 1919-1939. Bratislava.

\section{Zusammenfassung}

\section{Mit der Sehnsucht freizulegen... Die ersten zwanzig Jahre Staatliches Archäologisches Institut}

Die ersten zwanzig Jahre des Staatlichen Archäologischen Instituts waren von einer Reihe von Problemen begleitet, angefangen bei ungeeigneten Räumlichkeiten über begrenzte Finanzmittel bis hin zu einem Mangel an Facharbeitskräften. Die Grabungen - anfänglich vor allem Rettungsgrabungen - wurden von sog. Staatlichen Konservatoren durchgeführt, die mit Amateursammlern und regionalen Museumsmitarbeitern zusammenarbeiteten. Systematische Grabungen wurden 
lediglich mit der finanziellen Hilfe von weiteren Institutionen möglich gemacht, beispielsweise von Ministerien, Banken, Versicherungen und vor allem vom Nationalen Masaryk-Fonds. Die Statuten des Staatlichen Archäologischen Instituts von 1934 legten die Aufgaben der Institution fest, und zwar einschließlich einer zentralen Erfassung prähistorischer Funde. Vom Archiv für Fundberichte wurden jegliche Informationen über die auf dem Territorium der Republik gemachten Funde und durchgeführten Grabungen zusammengetragen. Das Konzept des Aufbaus eines Generalkatasters wurde vor allem von Jaroslav Böhm, dem späteren Direktor des Staatlichen Archäologischen Instituts durchgesetzt. Gleichzeitig stand er auch an der Spitze der Bemühungen um eine Modernisierung der Geländegrabungen, so arbeitete er unter anderem eine Methodik zur Leitung einer Geländegrabung bis zu ihrer Veröffentlichungsphase aus. Seine Bemühungen um die Ausarbeitung eines weiteren Entwicklungskonzepts des Staatlichen Archäologischen Instituts wurden jedoch unterbrochen, als das Protektorat Böhmen und Mähren ausgerufen wurde.

Mgr. Marcela Starcová, Ph.D., Archeologický ústav AV ČR, Praha, v. v. i., Letenská 4, 11801 Praha 1, Česká republika,starcova@arup.cas.cz 